\title{
ПРОЯВЛЕНИЕ ГИПЕРЧУВСТВИТЕЛЬНОСТИ ЗАМЕДЛЕННОГО ТИПА ПРИ ГНОЙНО-ВОСПАЛИТЕЛЬНОМ ПРОЦЕССЕ КАНДИДА- БАКТЕРИАЛЬНОЙ ЭТИОЛОГИИ В УСЛОВИЯХ ИММУНОСУПРЕССИИ
}

\section{THE MANIFESTATION OF DELAYED HYPERSENSITIVITY \\ IN THE PURULENT-INFLAMMATORY PROCESS OF CANDIDA-BACTERIAL ETIOLOGY UNDER CONDITIONS OF IMMUNOSUPPRESSION}

\section{E. Shatalova \\ O. Parahina \\ V. Khmelevskoy}

Summary. In the development of any issues of purulent-septic processes of mixed etiology, the study of the structure of pathogens of nosocomial infections in the medical institutions of the region is of primary and fundamental importance. Studies have shown a significant increase $(P<0.01)$ in the frequency of occurrence of fungi of the genus Candida spp., as the causative agent of HSP, in associations with various representatives of the domain of prokaryotic cells relative to monocultures (24.2\% and $3.7 \%$, respectively). It was found that the manifestation of delayed-type hypersensitivity in Candida-bacterial infection is directly dependent on the affiliation of the associated bacteria to the genus and species and is in a strong direct correlation $(r=0.987+0.090)$ with the dynamics of the clinical course of the burn wound, which is an indicator of the long-term persistence of pathogens of these symbioses in the body of immunosuppressed patients.

Keywords: mixed infections, immunosuppression, delayed-type hypersensitivity.

\author{
Шаталова Елена Васильевна \\ Д.б.н., профессор, ФГБОУВО «Курский \\ государственный медицинский университет» \\ Минздрава России \\ mikrobel@yandex.ru \\ Парахина Ольга Владимировна \\ К.п.н., старший преподаватель, ФГБОУ ВО «Курский \\ государственный медицинский университет» \\ Минздрава России \\ parahina-1970@mail.ru \\ Хмелевской Вадим Иванович \\ ФГБОУ ВО «Курский государственный медичинский \\ университет» Минздрава России \\ vadimdoctor42@yandex.ru
}

Аннотация. При разработке любых вопросов гнойно-септических процессов смешанной этиологии, изучение структуры возбудителей нозокомиальных инфекций в ЛПУ региона, имеет первостепенное и принципиальное значение. Исследования показали достоверное повышение $(\mathrm{P}<0,01)$ частоты встречаемости грибов рода Candida spp., как возбудителя ГСП, в ассоциациях с различными представителями домена прокариотических клеток относительно монокультур (24,2\% и 3,7\% соответственно). Установлено, что проявление ГЗТ при Кандида-бактериальной инфекции находится в прямой зависимости от принадлежности бактерий-ассоциантов к роду и виду и находится в сильной прямой корреляционной связи $(r=0,987+0,090)$ с динамикой клинического течения ожоговой раны, что служит показателем длительной персистенции возбудителей данных симбиозов в организме иммуносупрессированных больных.

Ключевые слова: смешанные инфекции, иммуносупрессия, гиперчувствительность замедленного типа.

микроорганизмы различного таксономического положения $[4,6]$.

С учетом этого, логично предположить, что наличие в ассоциации представителей различных доменов (домен «Eukaria», царство Fungi и домен «Bacteria» - прокариоты соответственно) может существенно влиять на становление иммунитета и, в частности, на формирование ГЗТ. Следует отметить, что известная способность бактериальных антигенов неспецифически изменять функцию клеток, принимающих участие в развитии ГЗТ, и биологические особенности представителей ассоци- 
аций могут значительно оказывать воздействие на развитие ГЗТ при смешанных инфекциях Кандида-бактериальной этиологии.

Кроме того, кандидоз по праву называется оппортунистической инфекцией, поражая в основном иммунокомпрометированный макроорганизм. При этом особые варианты взаимоотношений между грибами и бактериями могут приводить к повышению невысокого патогенного потенциала ассоциантов-возбудителей, что, в свою очередь, может определять неодинаковое формирование уровня ГЗТ, длительность гнойно-воспалительного процесса, продолжительность циркуляции возбудителей в организме и, как следствие,- влиять на эпидемиологию госпитальных инфекций (ГИ).

Между тем, все эти моменты в проблеме смешанных Кандида-бактериальных инфекций остаются не изученными ни с одного из параметров, характеризующих ГИ: ни с микробиологической, ни с иммунологической, ни с эпидемиологической позиций.

Целью данной работы явилось изучение проявления уровня ГЗТ при гнойно-воспалительном процессе Кандида-бактериальной этиологии у мышей в условиях иммуносупрессии.

\section{Метолика исслеАОвания}

Эксперименты выполнены на мышах линии СВА $(\mathrm{n}=240)$ массой 250-280 г., полученных из питомника лабораторных животных филиала ИБХ РАН (Пущино), прошедших карантинный режим вивария Курского государственного медицинского университета (КГМУ) и не имевших внешних признаков каких-либо заболеваний. Все животные содержались в одинаковых условиях на обычном пищевом режиме, при свободном доступе к воде и пище. Все исследования проводились с соблюдением принципов Европейской конвенции, директивы Европейского парламента и Совета Европейского Союза 2010/63/EC (от 22 сентября 2010 г.) по защите позвоночных животных, используемых для экспериментальных или иных научных целей, и в соответствии с решением регионального этического Комитета при КГМУ.

Видовую принадлежность выделенных микроорганизмов от больных определяли с помощью диагностических биохимических тест-систем Microla-Test («Lachema», Чехия). Интенсивность реакции (ИР) ГЗТ определяли путем сенсибилизации мышей эритроцитами барана (ЭБ) в дозе $1 \times 10^{7}$ с последующим введением разрешающей дозы ЭБ в подушечку правой задней лапы. В левую (контрольную) лапу - 0,85\% раствора хлорида натрия в том же объеме. Степень реакции оценивали через 24 ч [2].

С целью создания модели иммуносупрессии, на депилированном участке кожи спины животного под легким эфирным наркозом воспроизводили ожог III-B степени площадью около 30\% с помощью устройства, поддерживающего температуру обжигающей поверхности на уровне $100^{\circ} \mathrm{C}$ при экспозиции 8 сек. [3]. Для достижения поставленной цели и определения течения и исхода гнойно-септического процесса Кандида-бактериальной этиологии, через сутки после воспроизведения, ожоговую рану орошали свежеприготовленной смесью из одинакового количества микробных клеток грибов рода Candida albicans и разных видов бактерий-ассоциантов. Экспериментальное формирование ассоциаций возбудителей было основано на частоте выделения последних (представители домена «Bacteria») от больных при ГСП. Это были C. albicans+ St. aureus; C. albicans+ P. aeruginosa и C. albicans+ бактерии рода Acinetobacter (по 0,2 мл 1 млрдн. взвеси). Наблюдения за животными проводили в течение 32 суток, ежедневно учитывая количество павших животных.

Bсе полученные данные были подвергнуты статистической обработке с определением критерия Стьюдента с помощью пакета прикладных программ MS Excel и STATISTICA 13.3 Trial.

\section{Результаты и их обсужление}

Формирование у широких слоев населения иммунологических расстройств (ИР) является неопровержимым фактом нашего времени. На фоне таких ИР гнойно-воспалительные процессы (ГВП), в общем, и гнойно-септические процессы (ГСП) в основном в виде ГИ смешанной этиологии, в частности, неуклонно увеличиваются [1,5].

Такому явлению действительности способствует и то, что этиологическая структура возбудителей ГИ очень многообразна и значительно отличается своей разновидностью не только между географическими регионами, но и между отдельными ЛПУ и в настоящее время [1]. С учетом этого, разрабатывая любые вопросы ГСП смешанной этиологии, изучение структуры возбудителей ГИ в ЛПУ региона, имеет первостепенное и принципиальное значение.

Анализ структуры микробного спектра возбудителей ГИ многопрофильных стационаров г. Курска выявил следующие особенности. За период 2017-2020 гг. нами было изучено 362 штамма микроорганизмов, выделенных из патологического материала от больных ЛПу больничного типа. При этом значимыми возбуди- 


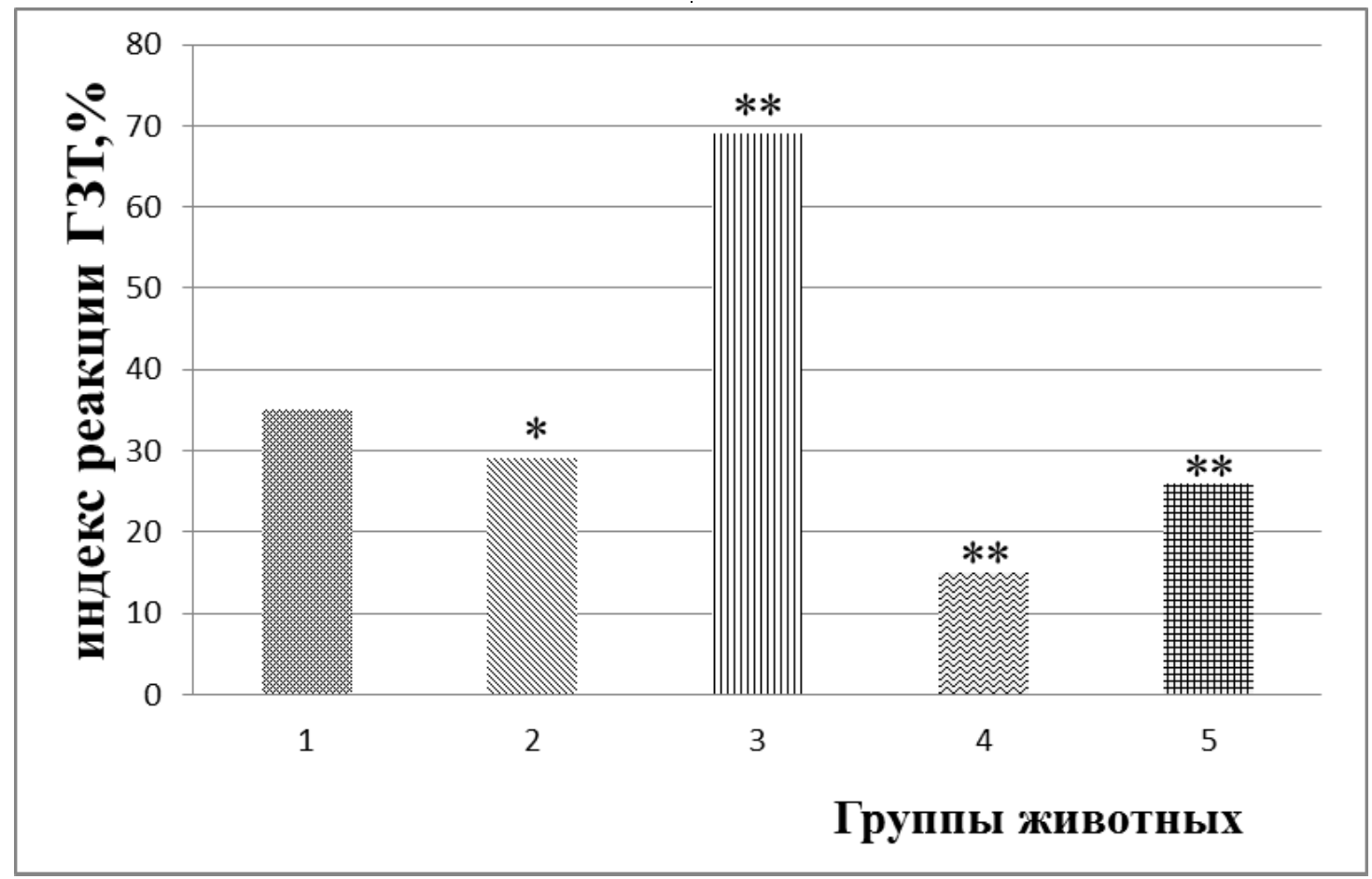

Рис. 1. Интенсивность реакции ГЗТ у животных с ожоговой травмой, осложненной Кандида-бактериальной инфекцией.

Примечание. Группы животных: 1 - интактные; 2 - ожог;

3 - ожог инфицирован C. albicans+ P. aeruginosa; 4 - ожог инфицирован C. albicans+ St. aureus; 5 - ожог инфицирован C. albicans+ Acinetobacter.

Достоверность различий с данными контрольной группы (интактные) - *P <0,05; ${ }^{*} \mathrm{P}<0,01$.

телями ГСП были бактерии рода Staphylococcus spp.110 (30,4\%) штаммов, грибы рода Candida spp.- 90 (24,9\%) штаммов, Pseudomonas aeruginosa - 65 (18,0\%) штаммов, бактерии рода Acinetobacter, Escherichia coli и Streptococcus pyogenes - $42(11,6 \%), 35(9,6 \%)$ и 20 (5,5\%) штаммов соответственно. Из них 255 (70,4\%) культур входили в состав различных ассоциаций, среди которых преобладали двухкомпонентные, однако, среди пациентов хирургических отделений с сопутствующей патологией, выделялась незначительная доля и трёхкомпонентных ассоциаций, что не совпадает с данными литературы [1]. Такая дивергентность структуры возбудителей ГСП ещё раз подтверждает данные литературы об обязательном включении блока параметров микробиологического мониторинга с целью своевременного выявления новых эпидемических штаммов - возбудителей ГИ. Следует отметить, что результаты наших исследований показали достоверное повышение $(\mathrm{P}<0,01)$ частоты встречаемости грибов рода Candida spp., как возбудителя ГСП, в ассоциациях с различными представителями домена прокариотических клеток относительно монокультур (24,2\% и 3,7\% соответственно). Доминирующим видом в течение всего периода наблюдения был C. albicans.
Между тем, до сих пор роль грибов рода Candida spp. во взаимоотношениях с различными другими представителями таксономических групп, равно как и влияние таких ассоциаций на иммунный ответ, течение и исход инфекционного процесса Кандида-бактериальной природы, изучено недостаточно.

Известно, что важным, а иногда и ведущим звеном в патогенезе разнообразных инфекционных осложнений, особенно грибковой этиологии, является формирование ГЗТ, основными действующими факторами которой являются активированные макрофаги. Однако, можно предположить, что на развитие ГЗТ при ГВП грибково-бактериальной природы существенно могут влиять и биологические особенности ассоциантов-возбудителей, которые способны стимулировать выделение гистамина из тучных клеток не только через цитофильные $\lg$ и и $\mathrm{lgG}$, но и при непосредственном их действии на клетку. Адъювантные свойства бактерий очень часто и во многом зависят от способности их антигенов неспецифически изменять функцию клеток, принимающих участие в развитии ГЗТ. Кроме того, следует отметить, что некоторые бактериальные фракции (например, пептидогликаны) вызывают неспецифиче- 
Таблица 1. Клиническое течение неинфицированной и инфицированной ожоговой раны.

\begin{tabular}{|c|c|c|c|c|c|}
\hline \multirow{2}{*}{$\begin{array}{l}\text { Характер } \\
\text { ожоговой раны }\end{array}$} & \multicolumn{5}{|c|}{$\begin{array}{l}\text { Клинические проявления в динамике (сутки) } \\
\text { M+m (n=25) }\end{array}$} \\
\hline & $\begin{array}{l}\text { Открытая } \\
\text { рана }\end{array}$ & $\begin{array}{l}\text { Формирование } \\
\text { струпа }\end{array}$ & $\begin{array}{l}\text { Наличие } \\
\text { гнойного } \\
\text { отделяемого }\end{array}$ & $\begin{array}{l}\text { Отпадение } \\
\text { струпа }\end{array}$ & $\begin{array}{l}\text { Полное } \\
\text { заживление }\end{array}$ \\
\hline $\begin{array}{l}\text { Неинффици- } \\
\text { рованная }\end{array}$ & $2,5+0,2$ & $4,9+0,8$ & - & $12,1+0,7$ & $14,2+0,5$ \\
\hline $\begin{array}{l}\text { Инфицированная } \\
\text { ассоциацией: }\end{array}$ & \multirow[b]{2}{*}{$5,1+0,9$} & \multirow[b]{2}{*}{$8,3+1,5$} & \multirow[b]{2}{*}{+} & \multirow[b]{2}{*}{$17,7+1,6$} & \multirow[b]{2}{*}{$20,3+1,9$} \\
\hline $\begin{array}{l}\text { C. albicans } \\
+ \\
\text { Acinetobacter }\end{array}$ & & & & & \\
\hline $\begin{array}{l}\text { C. albicans } \\
+ \\
\text { St. aureus }\end{array}$ & $7,1+1,8$ & $11,4+1,5$ & + & $21,2+1,7$ & $25,9+1,8$ \\
\hline $\begin{array}{l}\text { C. albicans } \\
+ \\
\text { P. aeruginosa }\end{array}$ & $\begin{array}{l}\text { Весь срок } \\
\text { наблюде- } \\
\text { ния } \\
\end{array}$ & - & $\begin{array}{l}\text { Весь срок } \\
\text { наблюде- } \\
\text { ния }\end{array}$ & - & $\begin{array}{l}\text { Не обнару- } \\
\text { жено до } \\
\text { конца набл. }\end{array}$ \\
\hline
\end{tabular}

ское торможение миграции макрофагов и часто являются митогенами для Т-лимфоцитов [2].

Нами впервые установлено, что по возрастанию интенсивности формирования реакции ГЗТ и тяжести вызываемой иммуносупрессии у животных, изученные ассоциации возбудителей ГСП располагаются в следующей последовательности: C. albicans+ Acinetobacter $\rightarrow$ C. albicans+ St. aureus $\rightarrow$ C. albicans+ P. aeruginosa. Учитывая эти обстоятельства, можно полагать, что такой последовательности расположения микобиоценозов, очевидно, предшествуют разнохарактерные взаимоотношения между грибами рода C. albicans и представителями домена «Bacteria».

Полученные нами результаты показывают, что у животных в ответ на ожоговую травму происходит угнетение ГЗТ $(\mathrm{P}<0,05)$. - рис. 1

На присоединившуюся Кандида-бактериальную инфекцию организм обожженных животных реагировал по-разному относительно формирования ГЗТ. При исследовании установлено, что разнонаправленное изменение уровня формирования ГЗТ у таких животных находится в прямой зависимости от принадлежности бактерий (участников данных симбиозов) к роду и виду.

Так, у животных с ожогом микобиоценозы, состоящие из C. albicans+ Acinetobacter и C. albicans+ St. aureus, вызывали достоверное угнетение ГЗТ (ИР = 26,0 $+1,1$ и $15,0+1,4$ соответственно).

Однако, в тех же условиях, ассоциация возбудителей из C. albicans+ P. aeruginosa формировала у последних гиперергическую реакцию ГЗТ (ИР $=69,0+2,6)$ - рис. 1.
Известно, что формирование чрезмерной ГЗТ во многих случаях приводит к значительным повреждениям тканей, которые утяжеляют течение ГВП и существенно осложняют течение основного заболевания. Полученные нами данные подтверждают это предположение.

Анализируя полученные нами результаты, отражающие клиническое течение инфицированной ожоговой травмы микроорганизмами изученных микобиоценозов у животных, следует отметить, что полное заживление «чистой» неинфицированной ожоговой раны наблюдалось на 14,2 + 0,5 сутки; инфицированная ассоциацией из возбудителей C. albicans+ Acinetobacter и C. albicans+ St. aureus - на 20,3 + 1,9 и 25,9 + 1,8 сутки соответственно.

Особого внимания заслуживает состояние ожоговой раны у животных, подвергнутых заражению ассоциацией из возбудителей C. albicans+ P. aeruginosa. Признаков заживления такой раны не наблюдалось на протяжении всего срока наблюдения. Клинические проявления ГВП у животных этой группы, наоборот, усугублялись за счет появления кровоточащих язв с гнойным отделяемым и, соответственно, увеличением ожоговой травмы в размерах (табл. 1) и регистрировались высокие показатели летальности таких животных.

Мы полагаем, что такой результат, можно объяснить развитием синергических взаимоотношений не только между псевдомонадами и грибами, но и продуктами их метаболизма.

Корреляционный анализ проявления ГЗТ при ГВП Кандида-бактериальной природы в условиях иммуно- 
супрессиии и динамикой клинического течения ожоговой раны позволил установить наличие сильной прямой связи между изучаемыми параметрами $(r=0,987$ $+0,090)$.

Полученные нами экспериментальные данные свидетельствуют о выраженном влиянии разнохарактерных взаимоотношений между возбудителями кандида-бактериальных микобиоценозов на формирование ГЗТ и динамику ГВП в условиях иммуносупрессии.

Выявленная особенность влияния возбудителей ГИ в условиях ассоциации с грибами C. albicans на формирование ГЗТ при ГВП имеет принципиальное зна- чение, служит показателем длительной персистенции возбудителей данных симбиозов в организме иммуносупрессированных больных, влияя при этом на эпидемиологию ГИ, и констатирует весомую значимость проблемы смешанных инфекций кандида-бактериальной природы.

\section{Б^аголарность}

Авторы выражают благодарность заведующей бактериологической лаборатории Шевцовой Юлии Александровне ОБУЗ «Курская городская больница скорой медицинской помощи» за организационную поддержку исследования.

\section{ЛИТЕРАТУРА}

1. Ватазин А.В., Зулькарнаев А.Б., Русанова Е.В., Будникова Н.Е. Возбудители бактериальной и грибковой инфекций в центре трансплантологии и диализа. Анализ динамики за восемнадцать лет (1998-2015). Вестник трансплантологии и искусственных органов. 2016, T XVIII.— № 2.—C. 56-64.

2. Клиническая иммунология и аллергология: в 3 т. / под ред. Л. Йегера.—М.: Медицина, 1990.— Т. 3.— 528 c.

3. Устройство для нанесения дозированного ожога мелким животным / В.В. Минухин, В.Г. Шамрай, Т.Н. Губина [и др.]. - 1985. - Деп. во ВНиимИ, № Д-9976

4. Шаталова Е.В. Смешанные инфекции: механизм формирования госпитальных штаммов в условиях ассоциации с грибами рода кандида: монография. Краснодар: Издательский Дом-Юг, 2016: 86 с.

5. Шаталова Е.В., Парахина О.В., Летова Ю.С. Персистентный потенциал значимых возбудителей нозокомиальных инфекций в условиях ассоциации с грибами рода Candida. Проблемы медицинской микологии. 2019; Т. 21, № 3. - C. 46-48.

6. Шкарин В.В., Ковалишена О.В., Саперкин Н.В., Шпрыкова 0.Н. Общая характеристика и проблемные вопросы полиэтиологичных инфекций, вызываемых условно-патогенными микроорганизмами. Журн. микробиол., 2017, № 6. — С. 114-126.

( ) Шаталова Елена Васильевна ( mikrobel@yandex.ru ), Парахина Ольга Владимировна ( parahina-1970@mail.ru ), Хмелевской Вадим Иванович (vadimdoctor42@yandex.ru ).

Журнал «Современная наука: актуальные проблемы теории и практики» 